\title{
Association between Transaminase Serum Levels and Severity of Dengue Hemorrhagic Fever among Hospitalized Adult Patients in South Tangerang Regional General Hospital
}

\author{
Femmy Nurul Akbar ${ }^{1}$, Mery Nitalia ${ }^{2}$, Meizi Fachrizal \\ Ahmad $^{3}$, Ahmad Sisjufri $M^{4}$ \\ ${ }^{1}$ Department of Internal Medicine, ${ }^{2}$ Department of Clinical \\ Pathology, ${ }^{3}$ Department of Parasitology, ${ }^{4}$ Medical Student \\ Syarif Hidayatullah State Islamic University \\ Jakarta, Indonesia
}

\author{
Silvia Dewi \\ ${ }^{4}$ Internal Medicine Clinic, South Tangerang Regional \\ General Hospital \\ Banten, Indonesia
}

\begin{abstract}
Liver dysfunction is one of complication in dengue infection. Manifestation could be enlargement of liver and mild to moderate increase of transaminase enzyme (SGOT \& SGPT) level. Transaminase level tend to be increase along with the severity of disease. This study aim to know characteristic of transaminase serum ( SGOT /SGPT) level increased in Dengue Hemorrhagic Fever (DHF) patients and also association between transaminase serum levels and grade of severity of DHF, especially in DHF grade I and II (based on WHO 2011 classification). This was an analytic observational study with cross sectional approached. Data were collected from adult DHF patients whom hospitalized in District General Hospital of South Tangerang in year 2014 - 2015 by using consecutive sampling method. Chi Square and Kolmogorov-Smirnov Statistic test were used in this study. From 157 samples, 9.1\% who had increased level of SGOT and $65.6 \%$ increased level SGPT respectively. Based on statistical test result, there is no significant association between grade of severity of dengue infection (DHF grade I \& II) and SGOT levels $(p=0.326)$ as well as SGPT levels $(p=0.664)$. There is no significant association between SGOT \& SGPT levels and grade of severity of dengue infection, especially DHF grade I \& II.
\end{abstract}

Keywords-Dengue hemorrhagic fever (DHF); DHF grade I; DHF grade II; transaminase serum; SGOT; SGPT; liver dysfunction

\section{INTRODUCTION}

Dengue fever (DF) and dengue hemorrhagic fever (DHF) are disease caused by dengue viral infection. This virus is transmitted by mosquitoes of the genus Aedes (Aedes aegypti $\&$ Aedes albopictus). The main clinical feature of this disease are fever, myalgia, retroorbital pain, petechie, bleeding manifestation, leukopenia, and trombositopenia.
It was estimated 50 million cases of dengue infection occurred each year. According to World Health Organization (WHO) data, in 2007, there are 150.000 cases (highest record) of dengue infection were reported in Indonesia and more than 25.000 cases were occurred in Jakarta and West Java. From 1968 to 2009, WHO recorded Indonesia as the country with the highest dengue infection cases in Southeast Asia [1].

TABLE I. WHO CLASSIFICATION OF DENGUE INFECTION AND GRADING OF SEVERITY (2011)

\begin{tabular}{|c|c|c|c|}
\hline $\begin{array}{l}\text { DF/ } \\
\text { DHF }\end{array}$ & Grade & Signs \& Symptoms & Laboratory \\
\hline DF & & $\begin{array}{l}\text { Fever with two of the } \\
\text { following: } \\
\text { - Headache } \\
\text { - Retro-orbital pain } \\
\text { - Myalgia } \\
\text { - Arthralgia/ bone pain } \\
\text { - Rash } \\
\text { - Hemorrhagic manifestations } \\
\text { - No evidence of plasma } \\
\text { leakage }\end{array}$ & $\begin{array}{ll}\text { - } & \begin{array}{l}\text { Leukopenia } \\
(\text { leukocyte } \leq 5000\end{array} \\
\left.\text { cell/mm } / \mathrm{mm}^{3}\right) \\
\text { - }\end{array}$ \\
\hline DHF & I & $\begin{array}{l}\text { Fever and hemorrhagic } \\
\text { manifestation (positive } \\
\text { tourniquet test) and evidence of } \\
\text { plasma leakage }\end{array}$ & $\begin{array}{l}\text { Thrombocytopenia } \\
<100.000 \text { cell } / \mathrm{mm}^{3} ; \\
\text { HCT increase } \geq 20 \%\end{array}$ \\
\hline DHF & II & $\begin{array}{l}\text { grade I plus spontaneous } \\
\text { bleeding }\end{array}$ & $\begin{array}{l}\text { Thrombocytopenia } \\
<100.000 \text { cell } / \mathrm{mm}^{3} \\
\text { HCT increase } \geq 20 \%\end{array}$ \\
\hline DHF & III & $\begin{array}{l}\text { Grade I or II plus circulatory } \\
\text { failure (weak pulse, narrow } \\
\text { pulse pressure } \leq 20 \mathrm{mmHg} \text {, } \\
\text { hypotension, restlessness) }\end{array}$ & $\begin{array}{l}\text { Thrombocytopenia } \\
<100.000 \text { cell } / \mathrm{mm}^{3} ; \\
\text { HCT increase } \geq 20 \%\end{array}$ \\
\hline DHF & IV & $\begin{array}{l}\text { grade III plus profound shock } \\
\text { with undetectable BP and pulse } \\
\text { rate }\end{array}$ & $\begin{array}{l}\text { Thrombocytopenia } \\
<100.000 \text { cell } / \mathrm{mm}^{3} ; \\
\text { HCT increase } \geq 20 \%\end{array}$ \\
\hline
\end{tabular}


WHO 2011 classified severity of dengue infection into 5 grades such as dengue fever (DF) and dengue hemorrhagic fever (DHF) grade I, II, III, \& IV [2]. (table I).

Liver dysfunction is one of the common results of dengue infection that often demonstrated by liver enlargement and mild-to-moderate increase of transaminase levels but jaundice and acute liver failure are not common [3].

Liver contains many enzymes which present in plasma in very low concentration. Elevation of those enzymes level in plasma mainly indicated liver cells damage. Aminotransferases enzyme are sensitive indicators of liver cell injury and are most helpful in detection of acute hepatocellular diseases, such as hepatitis [4]. Liver aminotransferase enzyme consist of Serum Glutamic Oxaloacetic Transaminase (SGOT) or Aspartate Aminotransferase (AST) and Serum Glutamic Pyruvate Transaminase (SGPT) or Alanine Aminotransferase (ALT) [5].

Based on study in Vietnam, Trung et al (2010) showed only $3 \%$ of dengue patient have normal SGOT \& SGPT levels. In addition SGOT level was found higher than SGPT in dengue infection [3].

Other study from India, Souza et al (2007) reported 169 patients with dengue infection, $65.1 \%$ had increased SGOT and SGPT levels; $48.5 \%$ increased less than 3 times from normal level, $14.8 \%$ increased 3 - 10 times from normal level, and $1.8 \%$ increased more than 10 times normal level [6].

Pathogenesis of liver dysfunction in dengue infection is not fully understood. Varying degrees of liver involvement are possibly caused by hepatocyte apoptosis directly by the virus or secondary to an aggressive host immune response to the virus, or reflects a complex interaction of these two mechanism $[3,7]$. In addition, hypoxic damage due to impaired liver perfusion resulting from fluid leakage causing shock, also have a role although acute liver failure is not always accompanied by shock condition. It was seen in study by Samitha et al who reported all subjects with severe dengue (SD) experienced liver dysfunction even none of them had shock [7].

Target cells of dengue virus infection in the liver are hepatocyte and Kupffer cell. Liver cells infection by dengue virus will lead to apoptosis of those cells. It was proved by biopsy and autopsy of more fatal cases that found necrosis of hepatocyte and hyperplasia of Kupffer cells. Some mechanisms believed to have a role in liver cells apoptosis: hypoxic dysfunction of mitochondria, effect from immune response, and viral cytopathy. After apoptosis, Councilman Bodies are left as it often found in histopathology examination $[3,7,8,9]$.

Early apoptosis of infected hepatocytes followed by their rapidly clearance by surrounding phagocytic cells may help to limit the spread of the dengue virus. This is might be for the reason of why jaundice in dengue fever not as severe as Yellow fever (group of flavivirus infection that also transmitted by Aedes aegypti) [10].
Factor that believed to influence the pattern of liver damage particularly in adult patients is the presence of previous chronic liver disease. In patients with history of hepatitis B or C, the liver dysfunction caused by dengue infection potentially more severe than patient who had no history of liver disease [8].

During dengue infection, monocyte, $\mathrm{B}$ cells, T cells, and mast cells produced large amount of cytokine. TNF alpha, IL2, IL-6, and IFN gamma reach the highest concentration in serum at the first 3 days of the disease while IL-10, IL-5, and IL-4 tend to appear lately. Dengue virus specific CD4+ and CD8+ T cells may result in liver cell damage by direct cytolitic effect and/ or mediated by cytokine [10]

In some studies it was found that there was a significant difference in laboratory test between patients with dengue fever and dengue hemorrhagic fever. The mean serum bilirubin, SGOT, and SGPT levels were higher in dengue hemorrhagic patients [11].

Shukla et al reported mean level of SGPT was 133 unit/L while SGOT was 267 unit/L. Although the mean level of SGOT found higher, there was no significant difference of mean level of SGOT and SGPT in patients with dengue fever and dengue hemorrhagic fever in their study. They found $100 \%$ patients had increased levels of SGOT and $91 \%$ had increased levels of SGPT [12].

Meanwhile Jnaneshwari et al found a significant correlation between grade of severity and SGOT $(p<0.001)$ and SGPT levels $(\mathrm{p}<0.001)$. Liver dysfunction is more severe in patients with DHF with or without shock. They reported $10 \%$ of patients with DHF and $100 \%$ of patients with dengue shock syndrome (DSS) had increased level of SGOT > 10 times normal value. Increased level of SGPT more than 10 times normal was found in $88.9 \%$ patients with DSS [16].

In general, SGOT levels increased more rapidly and its peak is higher than SGPT, and then decreased to normal level earlier than SGPT. This is unusual and different from what often found in acute hepatitis caused by viral hepatitis $[3,10]$.

The increased levels of SGOT maybe not only originated from liver cell damage but also from myocyte injury considering musculoskeletal symptoms that frequently accompany dengue infection such as myalgia or arthralgia. Although the myocyte injury still can not be assured, the creatinin kinase levels often found increased in acute phase of dengue infection $[3,13,16]$.

There are still limited studies about increased level of SGOT and SGPT in dengue viral infection in Indonesia.

Objectives of this study is to know characteristic transaminase level increased in DHF patients and association between increased serum SGOT \& SGPT levels and grade of severity of DHF, especially in DHF grade I and II (based on WHO 2011 classification). 


\section{METHOD}

This was an analytic observational study with cross sectional approach. Dengue hemorrhagic fever patients were consecutively enrolled this study. Data were collected from patient medical record in South Tangerang Regional General Hospital. Samples of this study were dengue hemorrhagic fever (DHF) patients that hospitalized in year 2014 to 2015 .

Inclusion criteria were DHF patients age $\geq 18$ years old who were hospitalized in General Hospital of South Tangerang and performed SGOT \& SGPT level laboratory test at $3^{\text {rd }}-7^{\text {th }}$ day of fever. Exclusion criteria were patient who had liver dysfunction caused by other than dengue infection such asviral hepatitis, typhoid fever, hepatic cirrhosis, hepatocellular carcinoma and patient with incomplete medical record data. The data were analyzed by Chi Square test and KolmogorovSmirnov test using SPSS 22.

\section{RESULT}

There were 157 subjects. Most subjects were female that was 80 patients $(51 \%)$ and the remains were 77 male subjects (49\%). 43 patients (27.4\%) come from age $25-34$ years old while only 4 patients $(2.5 \%)$ come from age $\geq 65$ years old. The youngest subject was 18 years and the oldest was 86 years with mean age of subjects is $35 \pm 13.96$ years old.

We used WHO 2011 classification and grading of severity in this study that classified dengue infection to dengue fever, DHF grade I, DHF grade II, DHF grade III, and DHF grade IV. However in the population of sample was only found patient with DHF grade I and II (table II). The grade of severity was according to data from medical record.

TABLE II. SUBJECTS DISTRIBUTION BASED ON GRADE OF SEVERITY OF DENGUE INFECTION

\begin{tabular}{|l|c|c|}
\hline $\begin{array}{c}\text { Grade of severity of } \\
\text { dengue infection }\end{array}$ & $\mathbf{n}$ & Percentage (\%) \\
\hline DHF grade I & 66 & 42 \\
\hline DHF grade II & 91 & 58 \\
\hline Total & 157 & 100 \\
\hline
\end{tabular}

From table II, the most grade of severity were DHF grade II as much 91 subjects (58\%).

\section{A. SGOT level}

Data about SGOT level in this study were collected from laboratory test performed in the first day of hospitalized with cutoff of normal value was $<37 \mathrm{U} / \mathrm{L}$. Increased level of SGOT in this study was classified into 4 categories:

1. Category A: Normal $(<37)$

2. Category $B$ : Mild increased, < 3 times normal value (37-107)
3. Category $C$ : Moderate increased, 3 to $<10$ times normal value (108-359)

4. Category $D:$ Severe increased, $\geq 10$ times normal value $(\geq 360)$

The result was presented in table III.

TABLE III.

UBJECT DISTRIBUTION BASED ON SGOT LEVELS

\begin{tabular}{|l|l|l|}
\hline \multicolumn{1}{|c|}{ SGOT Level } & \multicolumn{1}{c|}{ n } & Percentage (\%) \\
\hline Category A & 14 & 8.9 \\
\hline Category B & 74 & 47.1 \\
\hline Category C & 60 & 38.2 \\
\hline Category D & 9 & 5.7 \\
\hline
\end{tabular}

We found 74 subjects (47.1\%) had increased level of SGOT < 3 times normal value (37 -107 U/L). Sixty subjects $(38.2 \%)$ had increased 3 to $<10$ times normal value $(108-359$ $\mathrm{U} / \mathrm{L})$ and 9 subjects $(5.7 \%)$ had increased $\geq 10$ times normal value ( $\geq 360 \mathrm{U} / \mathrm{L})$. Only 14 subjects $(8.9 \%)$ had normal value of SGOT. The lower level of SGOT was $13 \mathrm{U} / \mathrm{L}$ while the highest was $1835 \mathrm{U} / \mathrm{L}$ with mean level was $154.97 \pm 226.45$ $\mathrm{U} / \mathrm{L}$

The characteristics of gender and age of patients who experienced increased SGOT level in various degree were presented in table IV.

TABLE IV

CHARACTERISTICS OF SUBJECTS WHO HAD INCREASED LEVEL OF SGOT

\begin{tabular}{|c|c|c|c|c|}
\hline \multirow{2}{*}{ Characteristics } & \multicolumn{4}{|c|}{ SGOT level } \\
\cline { 2 - 5 } & $\begin{array}{c}\text { Category } \\
\text { A (n= 14) }\end{array}$ & $\begin{array}{c}\text { Category } \\
\text { B (n= 74) }\end{array}$ & $\begin{array}{c}\text { Category } \\
\text { C (n= 60) }\end{array}$ & $\begin{array}{c}\text { Category } \\
\text { D (n= 9) }\end{array}$ \\
\hline Gender & \multicolumn{4}{|c|}{} \\
\hline Male & $7(50 \%)$ & $37(50 \%)$ & $26(43.3 \%)$ & $7(77.8 \%)$ \\
\hline Female & $7(50 \%)$ & $37(50 \%)$ & $34(56.7 \%)$ & $2(22.2 \%$ \\
\hline Age & & & \\
\hline $18-24$ & $2(14.3 \%)$ & $25(33.8 \%)$ & $10(16.7 \%)$ & $4(44.4 \%)$ \\
\hline $25-34$ & $4(28.6 \%)$ & $18(24.3 \%)$ & $20(33.3 \%)$ & $1(11.1 \%)$ \\
\hline $35-44$ & $4(28.6 \%)$ & $15(20.3 \%)$ & $13(21.7 \%)$ & $2(22.2 \%)$ \\
\hline $45-54$ & $2(14.3 \%)$ & $7(9.5 \%)$ & $13(21.7 \%)$ & $2(22.2 \%)$ \\
\hline $55-64$ & $2(14.3 \%)$ & $6(8.1 \%)$ & $3(5 \%)$ & $0(0 \%)$ \\
\hline$\geq 65$ & $0(0 \%)$ & $3(4.1 \%)$ & $1(1.7 \%)$ & $0(0 \%)$ \\
\hline
\end{tabular}

There was not so much difference between increased level of SGOT based on subject's gender. We only found that male $(77.8 \%)$ was higher than female $(22.2 \%)$ in patients with 
severe increased of SGOT level (category D). Based on age, patient who had normal level were dominated by age $25-34$ and 35 - 44 years old group (28.6\%). The most severely increased level of SGOT were $44.4 \%$ in subjects $18-24$ years old.

\section{B. SGPT Level}

Data about SGPT level in this study were collected from laboratory test performed in the first day of hospitalized with cut off of normal value was $<41 \mathrm{U} / \mathrm{L}$. Increased level of SGPT in this study was classified into 4 categories:

1. Category A: Normal $(<41)$

2. Category $B$ : Mild increased $<3$ times normal value (41 -119)

3. Category $C$ : Moderate increased, 3 to $<10$ times normal value (120-399)

4. Category D: Severe increased, $\geq 10$ times normal value $(\geq 360)$

The result was presented in table V.

TABLE V.

SUBJECTS DISTRIBUTION BASED ON SGPT LEVELS

\begin{tabular}{|l|c|c|}
\hline \multicolumn{1}{|c|}{ SGPT Level } & N & Percentage (\%) \\
\hline Category A & 54 & 34.4 \\
\hline Category B & 59 & 37.6 \\
\hline Category C & 40 & 25.5 \\
\hline Category D & 4 & 2.5 \\
\hline
\end{tabular}

We found that 59 subjects $(37.6 \%)$ had mild increased of SGPT level (category B). Forty subjects $(25.5 \%)$ had moderate increased (category C) and only 4 subjects $(2.5 \%)$ had severe increased level of SGPT. There were enough patients 54 (34.4\%) had normal level of SGPT. The lowest level of SGPT was $10 \mathrm{U} / \mathrm{L}$ while the highest level was $676 \mathrm{U} / \mathrm{L}$ with mean level was $95.03 \pm 63.00 \mathrm{U} / \mathrm{L}$.

The characteristics of gender and age of patients who experienced increased SGPT level in various degree were presented in table VI.

The percentage of increased levels of SGPT in both gender was not so much different. The highest percentage was $35 \%$ from subject with category $\mathrm{C}$ (moderate increased) that come from age $35-44$ years old. There was no subject age $>54$ years old who had severely increased level of SGPT.
TABLE VI

CHARACTERISTICS OF SUBJECTS WHO HAD INCREASED LEVEL OF SGPT

\begin{tabular}{|c|c|c|c|c|}
\hline \multirow{2}{*}{ Characteristics } & \multicolumn{4}{|c|}{ SGPT level } \\
\cline { 2 - 5 } & $\begin{array}{c}\text { Category } \\
\text { A (n= 54) }\end{array}$ & $\begin{array}{c}\text { Category } \\
\text { B (n= 59) }\end{array}$ & $\begin{array}{c}\text { Category } \\
\text { C (n= 40) }\end{array}$ & $\begin{array}{c}\text { Category } \\
\text { D (n= 4) }\end{array}$ \\
\hline Gender & \multicolumn{4}{|c|}{} \\
\hline Male & $25(46,3 \%)$ & $28(47,5 \%)$ & $22(55 \%)$ & $2(50 \%)$ \\
\hline Female & $29(53.7 \%)$ & $37(52.5 \%)$ & $18(45 \%)$ & $2(50 \%)$ \\
\hline Age & \multicolumn{5}{|c|}{} \\
\hline $18-24$ & $21(38.9 \%)$ & $12(20.3 \%)$ & $8(20 \%)$ & $0(0 \%)$ \\
\hline $25-34$ & $16(29.6 \%)$ & $12(20.3 \%)$ & $14(35 \%)$ & $1(25 \%)$ \\
\hline $35-44$ & $5(9.3 \%)$ & $17(28.8 \%)$ & $10(25 \%)$ & $2(50 \%)$ \\
\hline $45-54$ & $5(9.3 \%)$ & $13(22 \%)$ & $5(12.5 \%)$ & $1(25 \%)$ \\
\hline $55-64$ & $6(11.1 \%)$ & $3(5.1 \%)$ & $2(5 \%)$ & $0(0 \%)$ \\
\hline$\geq 65$ & $1(1.9 \%)$ & $2(3.4 \%)$ & $1(2.5 \%)$ & $0(0 \%)$ \\
\hline
\end{tabular}

C. Association between Transaminase Serum Levels and S Severity of Dengue HemorrhagicFever

This study showed there was no significant association between increased level of SGOT and grade of severity of dengue hemorrhagic fever $(\mathrm{p}=0.326)$ using Chi Square test (See table VII)

There was also no significant association between increased level of SGPT and grade of severity of dengue hemorrhagic fever using Kolmogorov-Smirnov test. $(p=0.664)$. (See table VIII).

TABLE VII

ASSOCIATION BETWEEN SGOT LEVELS AND DEGREE OF SEVERITY OF DENGUE INFECTION

\begin{tabular}{|l|c|c|l|c|c|}
\hline \multirow{2}{*}{$\begin{array}{c}\text { Grade of } \\
\text { Severity } \\
\text { of }\end{array}$} & \multicolumn{4}{|c|}{ SGOT Levels } & \multirow{2}{*}{ P } \\
\cline { 2 - 5 } $\begin{array}{c}\text { Dengue } \\
\text { Infection }\end{array}$ & $\begin{array}{c}\text { Category } \\
\text { A }\end{array}$ & $\begin{array}{c}\text { Category } \\
\text { B }\end{array}$ & Category C & $\begin{array}{c}\text { Category } \\
\text { D }\end{array}$ & \\
\hline $\begin{array}{l}\text { DHF } \\
\text { grade I }\end{array}$ & $9(13.6 \%)$ & $\begin{array}{c}31 \\
(47.0 \%)\end{array}$ & $23(34.8 \%)$ & $3(4.5 \%)$ & \multirow{2}{*}{0.326} \\
\hline $\begin{array}{l}\text { DHF } \\
\text { grade II }\end{array}$ & $5(5.5 \%)$ & $\begin{array}{c}43 \\
(47.3 \%)\end{array}$ & $37(40.7 \%)$ & $6(6.6 \%)$ & \\
\hline
\end{tabular}


TABLE VIII.

ASSLCIATION BETWEEN SGPT LEVELS AND DEGREE OF SEVERITY OF DENGUE INFECTION

\begin{tabular}{|c|c|c|c|c|c|}
\hline \multirow{2}{*}{$\begin{array}{c}\text { Grade of } \\
\text { Severity } \\
\text { of } \\
\text { Dengue } \\
\text { Infection }\end{array}$} & \multicolumn{4}{|c|}{ SGPT Levels } & \multirow{2}{*}{$\mathbf{P}$} \\
\hline & $\begin{array}{c}\text { Category } \\
\text { A }\end{array}$ & $\begin{array}{c}\text { Category } \\
\text { B }\end{array}$ & $\begin{array}{c}\text { Category } \\
\text { C }\end{array}$ & $\begin{array}{c}\text { Category } \\
\text { D }\end{array}$ & \\
\hline $\begin{array}{l}\text { DHF } \\
\text { grade I }\end{array}$ & $27(40.9 \%)$ & $16(24.2 \%)$ & $23(34.8 \%)$ & $0(0 \%)$ & \multirow{2}{*}{0.664} \\
\hline $\begin{array}{l}\text { DHF } \\
\text { grade II }\end{array}$ & $27(29.7 \%)$ & $43(47.3 \%)$ & $17(18.7 \%)$ & $4(4.4 \%)$ & \\
\hline
\end{tabular}

\section{DISCUSSION}

In this study, we found $91.1 \%$ subjects had increased levels of SGOT (table 4) and $65.6 \%$ subjects had increased levels of SGPT (table 5). This results was similar with the study by Shukla et al who reported $100 \%$ subjects had increased levels of SGOT and $91 \%$ had increased levels of SGPT. Also in the study of Kuo et al, they reported $93.3 \%$ subjects had increased level of SGOT and $82.2 \%$ had increased levels of SGPT $[12,13]$.

Increased levels of SGOT and SGPT in dengue virus infection is resulting from injury to the liver cells as dengue virus attack the reticulo-endothelial system of the host. This liver injury is not only resulted from direct effect of the virus but also could be caused by host immune responses [14].

Some theories about the pathogenesis of liver dysfunction in dengue infection has been postulated. One of them was involvement of cytotoxic T cell CD4+. Cytotoxicity of CD4+ cells occurred via two main pathways:

- $\quad$ Release of perforin and granzymes from activated $\mathrm{T}$ cell

- The interaction of Fas ligand on T cells with Fas on the target cells. This interaction can result in destruction of cells presenting viral antigens as well as nonantigenpresenting bystander cells that express Fas.

In addition, $\mathrm{T}$ cells were thought to produced cytokine/ chemocine that can damage the liver cells. In a study by Sung et al (2012), they reported increased expression of gene CXCL10 in dengue infection. CXCL10 is a gene that could resulted in recruitment of NK cells to liver organ and caused death of hepatocyte $[10,15]$.

The mean of SGOT levels in this study was $154,97 \pm$ 226,45 U/L and mean of SGPT levels was 95,03 \pm 63,00 U/L. These result are similar with other studies by Samitha et al, Jnaneshwari et al, Shukla et al, and Kuo et al who found that mean of SGOT level was higher than SGPT. This is due to SGOT enzyme is not only found in liver cells but also in other cells like muscle cell, myocard cell, kidney etc. Therefore in patient with dengue hemorrhagic fever, injury to the muscle cell also involved in increased levels of SGOT. Differ from SGOT, SGPT levels is more specific to evaluate the degree of liver cells damage because it mainly found in liver cells $[7,12,13,16]$.

Djossou et al also reported SGOT levels increased higher than SGPT but it tend to be return to normal value more rapidly than SGPT levels. It is possible because SGOT has a shorter half-life $(12.5-22 \mathrm{~h})$ than ALT $(32-43 \mathrm{~h})$ [17].

The difference between DHF grade I and II is the spontaneous bleeding manifestation of grade II. Sanusi et al, reported DHF patients with spontaneous bleeding had SGOT and SGPT levels significantly higher than those without bleeding $(p<0.05)$. Similar result also reported in other studies by Jnaneshwari et al and Rajoo et al that found average value of SGPT levels in DHF grade I was $83.64 \mathrm{U} / \mathrm{L}$ while in DHF grade II was $103.3 \mathrm{U} / \mathrm{L}$, however there were not significant difference SGPT values in grade I or II dengue fever in the study $(\mathrm{p}=0.385)[11,16,18]$.

Similar with previous study, there were also no significant difference between increased of level SGOT with degree of DHF (grade I or II) $(\mathrm{p}=0.326)$ and also with increased level of $\operatorname{SGPT}(\mathrm{p}=0.664)$

Based on study by Samitha et al that differentiated grade of severity into non-severe dengue (NSD) and severe dengue (SD), they found no significant difference in increased levels of SGPT but the SGOT levels was significantly higher in SD patients than NSD [7].

\section{Limitation of The Study}

In a study by Trung et al (2010) and Souza et al (2007), they found there was significant correlation between elevation of SGOT and SGPT levels and grade of severity of dengue infection. Compared to those studies, in this study the grade of severity found in subject population limited to DHF grade I and II whereas in those studies found subjects in a varying spectrum that were dengue fever (DF), dengue hemorrhagic fever, and dengue shock syndrome (DSS).

Another limitation in this study was the cross sectional design we used so we could not observed the elevation of SGOT and SGPT levels dynamically from day to day. The subjects were not performed serologic test to rule out the possibility of the patient had comorbid condition such as viral hepatitis.

\section{CONCLUSION}

There were $91.1 \%$ had increased level of SGOT and $65.6 \%$ had increased level of SGPT, among adult dengue hemorrhagic fever patients whom hospitalized in South Tangerang District General Hospital. Most increased levels of transaminase were mild-to-moderate level (category B and $\mathrm{C}$ ). There was no significant association between and increased levels of SGOT and grade of severity of dengue infection (DHF grade I and II) $(\mathrm{p}=0.326)$. There was no signficant association between and increased levels of SGPT and grade of severity of dengue infection (DHF grade I and II) $(\mathrm{p}=0.664)$ 


\section{Recommendation}

- It is necessary to do a similar study with varying subjects based on grade of severity such as dengue fever (DF), dengue hemorrhagic fever (DHF) grade I \& II, and dengue hemorrhagic fever grade III \& IV (DSS).

- It is necessary to do another study with primary data that more complete data can be obtained including all the outpatient and inpatient subjects.

- It is necessary to perform SGOT and SGPT laboratory test in all hospitalized dengue hemorrhagic fever patients.

\section{REFERENCES}

[1] Centre of data and epidemiological surveillance, Bulletin of jendela epidemiologi: main topic of dengue hemorrhagic fever. Jakarta: Ministry of health republic of Indonesia, 2010.

[2] World Health Organization, "Comprehensive guidelines for prevention and control of dengue and dengue haemorrhagic fever," India: WHO, 2011.

[3] D.T. Trung, L.T.T. Thao, T.T. Hien, et al., "Liver involvement associated with dengue infection in adults in Vietnam," Am J Trop Med Hyg, vol. 83, pp. 774-780, 2010.

[4] E.R. Schiff, M.F. Sorrel, W.C. Maddrey, Schiff's disease of the liver, $10^{\text {th }}$ ed. USA: Lippincott Williams \& Wilkins, pp. 35-36, 2007.

[5] Ministry of health republic of Indonesia, Guidelines for clinical data interpretation. Jakarta: Kemenkes RI, pp. 58-59, 2011.

[6] L.J. Souza, R.M.R. Nogueira, et al., "The impact of dengue on liver function as evaluated by aminotransferase levels," Brazilian Journal of Infectious Diseases, vol. 11, pp. 407-410, 2007.
[7] F. Samitha, W. Ananda, et al., "Patterns and causes of liver involvement in acute dengue infection," BMC Infectious Diseases, vol. 16, pp 1-9, 2016.

[8] J. Samanta, V. Sharma, "Dengue and its effects on liver," World J Clin Cases, vol. 3, pp. 125-131, Feb 2015.

[9] B.E.E. Martina, P. Koraka, A.D.M.E. Osterhaus, "Dengue virus pathogenesis: an integrated view," Clinical Microbiology Reviews, vol. 22, pp. 564-581, 2009.

[10] S.L. Seneviratne, G.N. Mlavige, H.J.D. Silva, "Pathogenesis of liver involvement during dengue viral infections," Royal Society of Tropical Medicine and Hygiene, vol. 100, pp. 608-614, 2005.

[11] S.F.S.A. Wahid, S. Sanusi, M.M. Zawawi, R.A. Ali, "A comparison of the pattern of liver involvement in dengue hemorrhagic fever with classic dengue fever," Southeast Asian J Trop Med Public Health, vol. 31 , pp. 259-263, Jun 2000.

[12] V. Shukla, A. Chandra, "A study of hepatic dysfunction in dengue," Journal of The Association of Physicians of India, pp. 460-461, Jul 2013.

[13] C.H. Kuo, D. Tai, et al., "Liver biochemical test and dengue fever," Am J Trop Med Hyg, vol. 47, pp. 265-270, 1992.

[14] A. Asim, H.A. Aftab, et al., "Assessment of dengue fever severity through liver function tests," Journal of the College of Physicians and Surgeons Pakistan, vol. 24, pp. 640-644, 2014.

[15] J.M. Sung, C.K. Lee, B.A. Wu-Hsieh, "Intrahepatic infiltrating NK and CD8 $\mathrm{T}$ cells cause liver cell death in different phases of dengue virus infection," PLoS ONE, pp. 1-9, 2012.

[16] M. Jnaneshwari, S. Jayakumar, et al., "Study of serum aminotransferase levels in dengue fever," $J$ of Evolution of Med and Dent Sci, vol. 3, pp. 244-255, 2014.

[17] F. Djossou, G. Vesin, G. Walter, et al., "Incidence and predictive factors of transaminase elevation in patients consulting for dengue fever in Cayenne Hospital, French Guiana," Trans R Sac Trop Med Hyg, vol. 110, pp. 134-140, 2016.

[18] S.C. Rajoo, G. Omesh, et al., "Liver function test in patients with dengue viral infection”, Dengue Bulletin, vol. 32, pp. 110-117, 2008. 